\title{
Herbicidal potential of agrochemicals of Sclerotium rolfsii against Parthenium hysterophorus
}

\author{
${ }^{I}$ Dr Ramanuj Patel* Deepika Patel* and A.K. Pandey ${ }^{3}$ \\ ${ }^{I}$ Department of Biological Sciences, R.D. University, Jabalpur- 482001 \\ ${ }^{2}$ Department of Zoology and Biotechnology research lab Government Sciences College Jabalpur \\ ${ }^{3}$ Chairmain Private University Regulatory Commission Board Bhopal M.P
}

\begin{abstract}
Herbicidal potential of CFCF (Cell free culture filtrate) of Sclerotium rolfsii against Parthenium hysterophorus was determined by shoot cut, seedling and detached leaf bioassays. Maximum phytotoxicity was obtained from 14 day's old fermented broth with Sucrose + Tween $20 @ 0.5 \%$ as formulating agent. Significant reduction in chlorophyll and protein contents of host was also noticed.
\end{abstract}

Key Words: Herbicidal potential, Sclerotium rolfsii, Parthenium hysterophorus, Biorational Phytotoxicity, Formulation

\section{Introduction}

Parthenium hysterophorus is an obnoxious, pernicious and deadly weed of compositae family native of North America, probably introduced in India along with grains under the PL 480 scheme. It poses serious threat to crops, livestock and human beings. Its infestation can be observed along railway lines, forest land, grassland and even valuable lands too. It is responsible for the substantial losses to the crops. It reduces agricultural yield by $40 \%$ and forage production by $90 \%$ (Knox et al., 2006). It has now gained the status of a major weed in forest areas of some states of India. It is gradually invading forest and other valuable lands. Conventional methods of its management rely mainly on the use of chemical herbicides. Public concern over the safety due to indiscriminate use of synthetic herbicides has generated significant pressures on weed scientists to search an alternative of these chemicals. Exploitation of microorganisms and especially their biorationals (natural products) as herbicides have generated significant interest world wide. (Pandey et al., 2002-2005). Survey conducted at various habitats of central India for weed pathogens yielded an isolate of Sclerotium rolfsii FGCC\#02 which incites severe collar rot disease in Parthenium (Pandey et al .,1996a). Mycoherbicidal potential of the pathogen is known to influence by environmental factors.

To overcome these constraints, secondary metabolites especially oxalic acid synthesized by the pathogen have also tried (Pandey et al.,2003). Oxalic acid produced by the pathogen showed high herbicidal potential against Parthenium. Normal application of oxalic acid did not produced noticeable results and need a suitable formulating agent for its effective herbicidal potential. Therefore, the present investigation deals with the formulation and in vitro evaluation of herbicidal potential of the pathogen against Parthenium by Seedling and Detached leaf bioassay.

\section{Recovery of Strains}

\section{Material And Methods}

S.rolfsii FGCC\#02 was obtained from Fungal Germplasm Collection Centre, R.D.University, Jabalpur, previously isolated from the diseased part of the target weed and maintained on Potato Dextrose Agar (PDA) medium as per Agrawal and Hasija (1986).

\section{Preparation and Extraction of CFCF}

$1000 \mathrm{ml}$ Erlenmeyer flasks containing $500 \mathrm{ml}$ of sterilized Richard's broth $\left(\mathrm{KNO}_{3}-10 \mathrm{~g} ; \mathrm{MgSO}_{4}-2.5 \mathrm{~g}\right.$; $\mathrm{KH}_{2} \mathrm{PO}_{4}-2.5 \mathrm{~g}$; Sucrose- $30 \mathrm{~g}$ and Distilled Water-1000ml) were seeded with $5 \mathrm{~mm}$ disc obtained from 7 days old cultures grown on PDA medium at $30^{\circ} \mathrm{C}$. Inoculated flasks were incubated at $30 \pm 2^{\circ} \mathrm{C}$ for 7 and 14 days. Fermented broth was filtered through Whatman's filter paper No.1 and the filtrate was centrifuged at $4000 \mathrm{rpm}$ for $10 \mathrm{~min}$ in a centrifuge (Remi). Supernatant was discarded and the crude filtrate was again passed through $0.25 \mu \mathrm{m}$ Sartorious filter in vacuo condition (Abbas et al., 1992). Oxalic acid production was also determined by the method suggested by Bateman and Beer (1965). Herbicidal potential of the agrochemicals of 7 and 14 days old was evaluated by detached leaf and seedling bioassay (whole plant bioassay).

\section{Detached leaf bioassay}

Leaves from the host target weed were surface sterilized with $2 \% \mathrm{NaOCl}$ and were kept on a sterilized moisture chamber prepared by using cotton and filter paper in a Petridish. (Thapar et al., 2002). Various 
dilutions of toxic metabolites $(5 \mathrm{ml})$ were used of 7 and 14 days old fermented broth viz., $25 \%, 50 \%, 75 \%$ and $100 \%$ and the effects were observed after $24 \mathrm{hrs}$. All the experiments were performed in triplicates.

\section{Seedling bioassay}

Seedlings were raised in pots $(10 \mathrm{~cm})$ containing soil, sand and peat in 1:1:1 ratio. Different concentration of S.rolfsii toxin (7 and 14 days old) was sprayed on host seedlings @ 30ml per plant and maintained in a green house (Temperature $30^{\circ} \mathrm{C} \&$ Relative humidity $85-90 \%$ ). Each treatment was replicated thrice with two control and observations were recorded after 3 days based on a score chart and percent disease index was calculated by using the following formula (Praveena 2003).

$$
\begin{aligned}
& \text { Sum of score each leaf }
\end{aligned}
$$

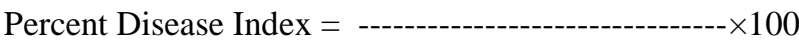

\section{Effect of CFCF on chlorophyll and protein contents}

$1 \mathrm{gm}$ of fresh leaves were homogenized with excess of ethanol in a mortar with pestle and centrifuged at $8000 \mathrm{rpm}$ for $2 \mathrm{~min}$, with $80 \%$ ethanol. Supernatant was taken in other flask and diluted with ethanol. Absorbance of the extract was measured by UV- Vis Systronics spectrophotometer at 645 and $663 \mathrm{~nm}$ for the determination of $\mathrm{Chl} \mathrm{a,} \mathrm{Chl} \mathrm{b} \mathrm{and} \mathrm{total} \mathrm{Chl.} \mathrm{The} \mathrm{protein} \mathrm{content} \mathrm{was} \mathrm{determined} \mathrm{as} \mathrm{per} \mathrm{Lowry} \mathrm{et} \mathrm{al} \mathrm{(1951).}$

\section{Formulation}

To test the compatibility of the toxin (14 days old) synthesized by the pathogen a total of 15 formulating agents namely Sorbitol, T-20+water, T-20+Sucrose, $\mathrm{H}_{2} \mathrm{O}+$ Gelatin, Toxin +Triton X 100, Toxin+ water, T-80+ sucrose $+\mathrm{H}_{2} \mathrm{O}$, Cween 80, Toxin, Toxin + Acrylamide, Toxin + Glycerol, Toxin + coconut oil, Toxin+Soyabean, Toxin+Mustard oil, Toxin+Tween 80 were tried. All the formulating agents were added at rate of $0.5 \%$ to the toxin and its herbicidal potential was determined by seedling assay and observations were made after $48 \mathrm{hrs}$ up to $10^{\text {th }}$ day. (Daigle and Conick 2002).

\section{Figures And Tables}

Table: 1 Effect of different concentration of toxin on host seedlings

\begin{tabular}{|l|l|l|}
\hline \multicolumn{3}{|c|}{ Incubation period } \\
\hline \multicolumn{3}{|c|}{$\%$ Disease index } \\
\hline Concentration & 7 days & 14 days \\
\hline $25 \%$ & $25 \pm 0.01$ & $36 \pm 0.04$ \\
\hline $50 \%$ & $59 \pm 0.04$ & $80 \pm 0.02$ \\
\hline $75 \%$ & $50 \pm 0.25$ & $75 \pm 0.25$ \\
\hline $100 \%$ & $48 \pm 0.01$ & $73 \pm 0.15$ \\
\hline Control & No effect & No effect \\
\hline
\end{tabular}

Amount of agrochemical sprayed: 30ml/plant; RH: $85 \%$; Values given in the table are mean \pm SEM

Table: 2 Effect of different concentration of toxin on detached leaves of Host

\begin{tabular}{|l|l|l|}
\hline \multicolumn{3}{|c|}{ Incubation period } \\
\hline \multicolumn{3}{|c|}{ \% Disease index } \\
\hline Concentration & 7 days & 14 days \\
\hline $25 \%$ & $33 \pm 0.01$ & $55 \pm 0.01$ \\
\hline $50 \%$ & $66 \pm 0.05$ & $95 \pm 0.25$ \\
\hline $75 \%$ & $52 \pm 0.02$ & $78 \pm 0.03$ \\
\hline $100 \%$ & $49 \pm 0.01$ & $70 \pm 0.01$ \\
\hline Control & No effect & No effect \\
\hline
\end{tabular}

Values given in the table are mean \pm SEM; Amount of agrochemical used: $5 \mathrm{ml} / \mathrm{plant}$; RH: 85

\begin{tabular}{|c|c|c|c|c|c|c|c|c|}
\hline \multirow[b]{3}{*}{ Concentration } & \multicolumn{7}{|c|}{ Biological Activity of CFCF } & \\
\hline & \multicolumn{4}{|c|}{7 Days } & \multicolumn{4}{|c|}{14 Days } \\
\hline & Chl.a & Chl.b & Total Chl.a & Protein & Chl.a & Chl.b & Total Chl.a & Protein \\
\hline $25 \%$ & $10.4 \pm 0.25$ & $12.1 \pm 0.06$ & $32.6 \pm 0.32$ & $36.1 \pm 0.04$ & $50.3 \pm 0.02$ & $40.8 \pm 0.02$ & $45.9 \pm 0.2$ & $35.5 \pm 0.04$ \\
\hline $50 \%$ & $72.1 \pm 0.07$ & $58.4 \pm 0.07$ & $65.4 \pm 0.28$ & $56.9 \pm 0.07$ & $97.8 \pm 0.01$ & $74.7 \pm 0.02$ & $72.5 \pm 0.07$ & $76.1 \pm 0.01$ \\
\hline $75 \%$ & $68.8 \pm 0.04$ & $56.1 \pm 0.65$ & $60.3 \pm 0.62$ & $36.9 \pm 0.04$ & $82.2 \pm 0.25$ & $68.5 \pm 0.01$ & $65.3 \pm 0.2$ & $54.1 \pm 0.01$ \\
\hline $100 \%$ & $69.6 \pm 0.05$ & $53.4 \pm 0.025$ & $59.9 \pm 0.73$ & $27.8 \pm 0.07$ & $78.1 \pm 0.01$ & $65.2 \pm .03$ & $63.4 \pm 0.3$ & $42.2 \pm 0.02$ \\
\hline Control & No effect & No effect & No effect & No effect & No effect & No effect & No effect & No effect \\
\hline
\end{tabular}

Table: 3 Effect of different concentration of toxin on biological contents of host seedlings

Values given in the table are mean \pm SEM;Amount of agrochemical sprayed: 30ml/plant; RH: $85 \%$ 
Table: 4 Effect of different formulations on host seedlings under green house conditions

\begin{tabular}{|c|c|c|c|c|c|c|}
\hline \multirow[t]{2}{*}{ SNo } & \multirow[t]{2}{*}{ Formulating agent } & \multicolumn{5}{|c|}{$\%$ Disease intensity } \\
\hline & & $2^{\text {nd }}$ day & $4^{\text {th }}$ day & $6^{\text {th }}$ day & $8^{\text {th }}$ day & $10^{\text {th }}$ day \\
\hline 1 & Sorbitol & 1 & 4 & 4 & 4 & 4 \\
\hline 2 & T-20+water & 2 & 5 & 5 & 5 & 5 \\
\hline 3 & T-20+Sucrose & 5 & 6 & 6 & 6 & 6 \\
\hline 4 & $\mathrm{H}_{2} \mathrm{O}+$ Gelatin & 5 & 5 & 5 & 5 & 5 \\
\hline 5 & Toxin +Triton X 100 & 2 & 5 & 5 & 5 & 5 \\
\hline 6 & Ioxin+ water & 5 & 5 & 6 & 6 & 6 \\
\hline 7 & $\mathrm{~T}-80+$ sucrose $+\mathrm{H}_{2} \mathrm{O}$ & 4 & 3 & 4 & 5 & 5 \\
\hline 8 & Cween 80 & 2 & 4 & 4 & 4 & 4 \\
\hline 9 & Toxin & 6 & 6 & 6 & 6 & 6 \\
\hline 10 & Toxin + Acrylamide & 2 & 4 & 4 & 4 & 4 \\
\hline 11 & Toxin+ Glycerol & 1 & 1 & 1 & 1 & 1 \\
\hline 12 & Toxin+coconut oil & 1 & 1 & 1 & 1 & 1 \\
\hline 13 & Toxin+Soyabean & 3 & 3 & 3 & 3 & 3 \\
\hline 14 & Toxin+Mustard oil & 3 & 3 & 3 & 4 & 4 \\
\hline 15 & Toxin+Tween 80 & 6 & 7 & 8 & 9 & 9 \\
\hline 16 & Control (Richard'sbroth) & No Effect & No Effect & No Effect & No Effect & No Effect \\
\hline & SEM & \multicolumn{5}{|l|}{ \pm 0.33} \\
\hline & $\mathrm{CD}_{5 \%}$ & \multicolumn{5}{|l|}{0.946} \\
\hline
\end{tabular}

Disease rating index (Horsfall and Barret 1945)

$1=99 \%, 2=95 \%, 3=91 \%, 4=82 \%, 5=62 \%, 6=38 \%, 7=18 \%, 8=9 \%, 9=5 \%, 10=1 \%$ )

Amount of agrochemical sprayed: 30ml/plant; RH: $85 \%$; Incubation period: 14 days

\section{Seedling bioassay}

\section{Results And Conclusion}

It is clearly evident from the data recorded in Table 1 that CFCF obtained from different incubations has varied effect on host seedlings. Maximum average leaf area damage (ALAD) of $85 \%$ on the seventh day and $65 \%$ of leaf damage by fourth day was observed when treated with CFCF obtained from 14 day's old fermented broth at 50\% concentration followed by 75 and 100\%. CFCF obtained from 14 days old fermented broth showed the maximum toxicity due to the maximum production of oxalic acid. CFCF obtained from 7 days old fermented broth also showed considerable toxicity at higher concentration. Similar observations have also reported by many other workers. (Pandey et al., 2002; Winder and Watson 1994; Saxena and Pandey 2001; Saxena et al., 2001) In contrast to this, several workers recorded maximum toxin production after 7 days of incubation.(Pandey et al., 2003) While the CFCF obtained from $14 \mathrm{~d}$ old fermented broth showed the maximum mortality to the host seedlings, 7 days old broth didn't cause significant damage to the host seedlings.. Similar findings have also been made by 'other workers. (Abbas et al., 1995; Shukla and Pandey 2006). Each experiment was performed in triplicates. The means of experiment was analyzed by one way ANOVA which indicates significant difference between the mean leaf area damage at different concentration with a $\mathrm{P}$ value of $5 \%$.

\section{Detached leaf assay}

Noticeable symptoms were also observed when detached leaves were treated with CFCF of 7 and 14 days old fermented broth at various concentrations viz., 25, 50, 75 and 100\%. Leaves were completely killed at $100 \%$ concentration and more than $80 \%$ of damage was recorded at $50 \%$ concentration (Table 2). Results obtained by detached leaf assay were quite prompting to use this pathogen as herbicidal agent against the weed. Similar damage ratings were also recorded by other workers (Joseph et al., 2002). One way ANOVA which indicates significant difference between the mean leaf area damage at different concentration of toxin with a $\mathrm{P}$ value of $5 \%$.

\section{Effect on chlorophyll and protein contents}

Chlorophyll and protein contents were also significantly affected when treated with CFCF. The contents were gradually decreased with increased incubation. Maximum reduction was recorded in leaves treated with CFCF obtained from 14 days old fermented broth at 50\% concentration followed by $75 \%$ and 100 $\%$ (Table 3). $14 \mathrm{~d}$ old fermented broth showed the maximum biological activity as depicted by the significant reduction in the chlorophyll and protein content of the host leaves. While extract obtained from 7 days old broth failed to show any remarkable reduction in these contents at similar concentration. The effect was comparatively more on chlorophyll a and total chlorophyll while chlorophyll $\mathrm{b}$ and protein contents were less affected. Variation in toxicity in relation to incubation period may be due to different phase of growth of the fungus. Metabolites required for own growth are normally synthesized during initial phase whereas most of the toxicants 
are formed during idiophase i.e. stationary phase of the fungus. (Abbas et al., 1995) also recorded 25 to $78 \%$ reduction in chlorophyll content in Datura sp. (jimson weed) tissues treated with fumonisin. Similarly significant biological activity of CFCF of many other microorganism including fungi have also recorded by several workers.( Sharma et al., 2004; Thapar et al., 2002; Abbas et al., 1995; Joseph et al., 2002; Saxena and Pandey 2001; Saxena et al., 2001 ; Kovics et al., 2005; Pandey and Pandey 2005).

\section{Formulation}

Data recorded in Table.4 clearly depicts that maximum phytotoxicity was shown by the toxin formulated with Sucrose + Tween 20 followed by Tween-80.Triton X was found to be highly inhibiting in its action. Rest of the agents produced average effect on the host shoots. Findings obtained in the above study clearly revealed the herbicidal potential of the pathogen against Parthenium. Maximum toxicity obtained at 50\% concentration with sucrose +Tween 20 indicates the toxin compatibility with the formulating agent. However, others did not produce significant damage to the host seedling. Variations in different formulation may be due to the compatibility of the organism with various formulating agent. Similar findings have also been made by Singh (2002).

The above findings clearly indicate that the present isolate have significant potential to produce phytotoxic compounds with high herbicidal properties against P. hysterophorus. However, detailed investigation regarding characterization, standardization of large scale production of herbicidal compounds are to be carried out before its field application.

\section{Acknowledgement}

We are grateful to Head Department of Biological Sciences, R.D.University, and Jabalpur for providing necessary laboratory facilities.

\section{References}

[1]. A.K. Pandey., J. Mishra, R.C. Rajak and S.K. Hasija, (1996a), Potential of indigenous strains Sclerotium rolfsii Sacc. For the management of Parthenium hysterophorus L. a serious threat to biodiversity in India. In: Herbal Medicines, Biodiversity and Conservation Strategies (R.C. Rajak \& M.K. Rai eds), International Book Distributors, Dehra Dun, pp. 104-138.

[2]. A.K. Pandey., S. Gayathri, R.C. Rajak and S.K. Hasija, (1996) Possibilities, problems and prospects of microbial management of Parthenium hysterophorus in India. In: Perspectives in Biological Science (V.Rai, M.L.Naik \& C. Manoharachary eds.), School of life Sciences, Pt. R.S. Shukla University, Raipur, pp. 253-267

[3]. A.K. Pandey., R.C. Rajak., S. Gayatyri and S.K. Hasija, (1997) Preliminary Assessment of Colletotrichum dematium as a mycoherbicide against P. hysterophorus L In: Achievements and Prospects in Mycology and Plant Pathology.(S.S. Chahai, L.B. Prashar, H.S. Randhwa \& S. Arya eds). International Book Distributors, Dehradunpp.59-85.

[4]. A.K. Pandey., Jaya Singh and M.A. Varghese (1999). Effect of Rhizobacteria on Parthenium PCIN 31:1-6

[5]. A.K. Pandey., Jaya Singh, G. M. Shrivastava and R. C. Rajak. (2003) Fungi as herbicides: Current status and future prospects In: Plant Protection: A Biological Approach (Trivedi P.C. ed) Aavishkar Publishers, Distributors Jaipur, India, pp. 305-339.

[6]. A.K Pandey., G.M. Shrivastava, A. K. Singh \& S. K. Verma (2003) Herbicidal potential of secondary metabolites of Sclerotium rolfsii against Parthenium: A preliminary observation. J. Basic Appl. Mycol 2(1): 27-30

[7]. A.K. Pandey (2001). Microorganisms associated with weeds; opportunities and challenges for their exploitation as herbicides, Int. J. Mendel. 17: 59-62

[8]. A.K.Pandey, Poonam Chandla and R. C. Rajak, (2002) Herbicidal Potential of Secondary metabolites of some fungi against Lantana camara L. J. Mycol. Pl. Pathol 32: 100-102.

[9]. Archana Pandey and A.K. Pandey (2005) Preliminary assessment of Colletotrichum dematium as a potential mycoherbicide against Hyptis suaveolens. J. Basic Appl. Mycol., 4, 21-22

[10]. Archana Pandey., A.K. Pandey and R.C. Rajak (2002) Mycoherbicidal potential of S.rolfsii against Hyptis suaveolens L Poit J. Trop. Forestry. 18 (1\&2): 96-98

[11]. D.F. Bateman and S.V. Beer (1965). Simultaneous productions and synergistic action of oxalic and polygalacturonase during pathogenesis by Sclerotium rolfsii. Phytopathol 55: $204-211$

[12]. G.J. Kovics, A.K. Pandey and M.K. Rai,( 2005) Phoma Saccardo and related genera: Some New Perspectives in Taxonomy and Biotechnology In: Biodiversity of fungi: their role in human life (Eds. S.K. Deshmukh \& M. K. Rai), Science Publishers Inc. Enfield (NH), USA. Plymouth, UK, pp. 129-153.

[13]. H.L. Walker and G.E.Templeton (1978) In vitro production of a phototoxic metabolite by Colletotrichum gleiosporoides F.sp Aeschynomene Plant Sci. Letters. 13: 91-96

[14]. H.K. Abbas., C.D. Boyette H.K. Abbas., C.D. Boyette and R.C. Hoagland., Phytoprotect. 76:17-25 (1995).

[15]. Boyette, and R.C. Hoagland (1995). Phytotoxicity of Fusarium, other fungal isolates and of the phytotoxins fumonisins, fusaric acid and moniliformin to jimson weed. Phytoprotection 76: 17-25

[16]. H.K. Abbas., W.C.A. Glederbloom, M.K. Cawood and W.T. Shier (1993). Biological activities of fumonisin mycotoxins from Fusarium moniliformin ,in jimson weed.(Datura stramoniumL.) and mammalian cell cultures. Toxicon. 31: 345-353.

[17]. H.K. Abbas., C.D. Boyette and R.C. Hoagland., (1995). Phytoprotect. 76:17-25

[18]. Knox, Jai, Anita Dass, Manjula Thomas and M.S. Paul (2006). Management of Parthenium hysterophorus L. through Atrazine with Cassia uniflora extract. Ann. Pl. Protec. Sci.14 (2):

[19]. 31:1-6

[20]. P. Sharma. S .R. Sharma and Sindhu (2004) Indian Phytopath. 53 (3): 315-318

[21]. Riti Thapar., A.K. Singh, Archana Pandey and A.K. Pandey (2002) Bioactivity of CFCF of Curvularia lunata in Parthenium hysterophorus L., J.Basic Appl.Mycol. I:126-129.

[22]. O.H.Lowry., Rosebrough, A.L. Fan and R.J. Randa (1951) Protein measurement with the follinphenol reagent. J. Biol. Chem. 193: $265-275$ 
[23]. R.K. Grover and B.L. Chona, (1960). Comparative studies on Sclerotium rolfsii sacc. And ozonium texanum neal and werster var. Parasiticum Thirumalachar Indian Phytopath., 13; 118-129

[24]. Rekha Shukla and A.K. Pandey (2006) Maximization of production of oxalic acid from Sclerotium rolfsii, a mycoherbicidal agent against parthenium. Ann. Pl. Protect. Sci, 14(1): 202-205

[25]. R.S.Winder and K. Watson (1994) Phytoprotection. 74(1): 19-23.

[26]. S. Joseph., S. Lal and A.K. Pandey (2002) Preliminary evaluation of herbicidal potential of Streptomyces WC\#150 against Lantana camara. .Ann .Pl. Protec. Sci. 10:134-136

[27]. Sanjai Saxena and A. K. Pandey (2001) Microbial metabolites as ecofriendly agrochemicals for the next millennium. App. Microbial Biotechnol. 55: 395-403

[28]. Sanjai Saxena, A.K. Pandey and R.C. Rajak (2001) Potential of an idiolite from Alternaria alternata as biorational agrochemicals In: Frontiers in Fungal Biotechnology and Plant Pathogen Relationships (C. Manoharachary, G. Bagyanarayana, B. Bhadraiah, K.Satyaprasad, B.N. Reddy \& A. Nagmani eds.). Allied Publishers, Hyderabad, pp.22-28

[29]. Sanjai Saxena and A. K.Pandey (2002) Evaluation of an indigenous isolate of Alternaria alternata (LC\#508) for use as a mycoherbicide for Lantana camara L. Crop Protection., 21: 71-73.

[30]. Sanjai Saxena, A.K. Pandey and R.C. Rajak (2000). Preliminary evaluation of fungal metabolites as natural herbicides for the management of Lantana camara. , Indian Phytopath. 53: 490-493 